\title{
A new species of Notalina Mosely, 1936 (Trichoptera: Leptoceridae) from Southeastern Brazil
}

\author{
Ana Lucia Henriques-Oliveira ${ }^{1,4}$, Márcia Regina Spies² \& Leandro Lourenço Dumas ${ }^{1,3}$ \\ ${ }^{1}$ Laboratório de Entomologia, Instituto de Biologia, Universidade Federal do Rio de Janeiro, \\ Ilha do Fundão, Cidade Universitária, CP 68044, CEP 21944-970, Rio de Janeiro, RJ, Brazil. \\ Bolsista PAPD-FAPERJ \\ ${ }^{2}$ Universidade Federal do Pampa - UNIPAMPA, Av. Antônio Trilha, 1847, \\ CEP 97300-000, São Gabriel, RS, Brazil \\ ${ }^{3}$ Bolsista Doutorado $\mathrm{CNPq}$ \\ ${ }^{4}$ Corresponding author: Ana Lucia Henriques-Oliveira, e-mail: anahenri@biologia.ufrj.br
}

HENRIQUES-OLIVEIRA, A.L., SPIES, M.R. \& DUMAS, L.L. A new species of Notalina Mosely, 1936 (Trichoptera: Leptoceridae) from Southeastern Brazil. Biota Neotrop. 12(4): http://www.biotaneotropica. org.br/v12n4/en/abstract?article+bn03012042012

\begin{abstract}
The Neotropical subgenus Notalina (Neonotalina) Holzenthal, 1986 has ten described species in two species groups: brasiliana, formed by seven species from Southeastern Brazilian and Goiás State; and roraima, represented by three species from the Amazonian and Andes regions. In this paper, a new species of Notalina is described and illustrated from specimens collected in the Mantiqueira mountain range, Southeastern Brazil. The new species belongs to the brasiliana group and is easily recognized by the poorly developed dorsomesal and ventrolateral processes and the pair of mound-like protuberances located mesolaterally on abdominal segment $\mathrm{X}$, and by the robust, rounded mesoventral processes and long digitate mesodorsal processes of the inferior appendages. A key to the Neotropical species in the genus is provided.
\end{abstract}

Keywords: Atlantic Forest, Neotropical, Hudsonemini, new species, identification key.

HENRIQUES-OLIVEIRA, A.L.; SPIES, M.R. \& DUMAS, L.L. Nova espécie de Notalina Mosely, 1936 (Trichoptera: Leptoceridae) do Sudeste do Brasil. Biota Neotrop. 12(4): http://www.biotaneotropica.org.br/ v12n4/pt/abstract?article+bn03012042012

Resumo: O subgênero Neotropical Notalina (Neonotalina) possui dez espécies descritas em dois grupos: brasiliana, formada por sete espécies provenientes do Sudeste brasileiro e do Estado de Goiás; e roraima, representado por três espécies das região Amazônica e Andes. Neste trabalho, uma nova espécie de Notalina é descrita e ilustrada a partir de espécimes coletados na Serra da Mantiqueira, Sudeste do Brasil. A nova espécie pertence ao grupo brasiliana e é facilmente reconhecida por processos dorsomesal e ventrolateral pobremente desenvolvidos e por um par de pequenas protuberâncias localizadas mesolateralmente no segmento X, apêndices inferiores com processo mesoventral arredondado e robusto, e processo mesodorsal longo e digitado. Uma chave de identificação para as espécies neotropicais do gênero é fornecida.

Palavras-chave: Mata Atlântica, Região Neotropical, Hudsonemini, espécie nova, chave de identificação. 


\section{Introduction}

Leptoceridae (or long-horned caddisflies) are among the three largest families of Trichoptera, with about 1,800 described species and 46 extant genera (Malm \& Johanson 2011). The family is currently divided into four subfamilies: Leptocerinae Leach, 1815, with cosmopolitan distribution, Triplectidinae Ulmer, 1906 and Grumichellinae Malm \& Johanson, 2011, both with primarily Southern Hemisphere distribution in the Neotropics and Australasia, and Leptorussinae Malm \& Johanson, 2011, with only the monotypic genus Leptorussa Mosely, 1953 from Australia (Holzenthal 1986, Morse \& Holzenthal 1987, Malm \& Johanson 2011).

The genus Notalina Mosely, 1936, which belongs to the subfamily Triplectidinae, tribe Hudsonemini, contains 25 species distributed in two subgenera: $N$. (Notalina) Mosely, 1936, with 15 species endemic to Australia and Tasmania, and N. (Neonotalina) Holzenthal, 1986, with 10 species exclusively South American in distribution (Calor 2008). The genus is especially diverse in Brazil, where there are seven species described: N. brasiliana Holzenthal 1986, N. cipo Holzenthal 1986, N. froehlichi Calor \& Holzenthal 2006, N. goaianensis Calor, 2008, N. hamiltoni Holzenthal 1986, N. morsei Holzenthal 1986, and N. paulista Calor \& Holzenthal 2006 (Holzenthal 1986, Calor et al. 2006, Calor 2008).

Holzenthal (1986) recognized two species groups of Neotropical (roraima and brasiliana groups). The roraima species group occurs in the upper Amazon basin, the Northern Andes, and the Guiana Highlands, while species of the brasiliana species group are found in the highlands of Southeastern and Central Brazil (Calor 2008). Herein, a new species of Notalina (Neonotalina) from the Mantiqueira mountain range, Southeastern Brazil is described and illustrated.

\section{Materials and Methods}

The specimens were collected with Pennsylvania light traps (Frost 1957), Malaise traps, and hand net at Parque Estadual de Campos do Jordão (São Paulo State) and the upper portion of the Itatiaia massif, Itamonte municipality (Minas Gerais State), both located in the Mantiqueira mountain range, an Atlantic Forest highland area of Southeastern Brazil.

The material examined was preserved in $80 \%$ alcohol. To observe genital structures, the abdomen was removed and cleared in $10 \%$ $\mathrm{KOH}$ solution. Both stereo- and optical microscopes were used to examine specimens and specimens were illustrated with the aid of a camera lucida. Morphological terminology follows that of Holzenthal (1986). The type specimens are deposited in Museu de Zoologia, Universidade de São Paulo, Brazil (MZSP), and the Coleção Entomológica Prof. José Alfredo Pinheiro Dutra, Departamento de Zoologia, Universidade Federal do Rio de Janeiro, Rio de Janeiro, Brazil (DZRJ).

\section{Taxonomy}

\section{Notalina jordanensis, new species}

Notalina jordanensis belongs to the brasiliana species group as defined by Holzenthal (1986), by sharing the phallobase with paired, lateral, acuminate flanges and the large, well developed phallotremal sclerite. The new species is most similar to $N$. brasiliana and $N$. goianensis, due to the general structure of saddle-like segment $\mathrm{X}$. However, $N$. jordanensis has the dorsomesal and ventrolateral processes poorly developed on abdominal segment $\mathrm{X}$ and has a mound-like protuberance mesolaterally, absent in the other species. Furthermore, the robust and rounded mesoventral processes and the long digitate mesodorsal processes of the inferior appendages, are also useful diagnostic characters for the new species.
Adult: Color (in alcohol) brown to dark brown; legs, palps, and antennae brown. Tibial spur formula 2,2,4. Wing venation as in Figure 1; forewing with forks I, and V presents, with small clear area dorsoapically at thyridial cell; hindwing with forks I, III, and V presents. Forewing length 9.2-10.4 $\mathrm{mm}(\mathrm{n}=8)$.

Male genitalia: Abdominal segment IX annular, broadest ventrolaterally, with pair of small dorsal expansions and setae on lateral edge (Figures 2, 3). Segment X saddle-shaped, with setose, mound-like protuberance mesolaterally, and bearing pair of small ventrolateral processes apically and pair of poorly developed dorsomesal processes (viewed only in dorsal view) (Figures 2, 3). Preanal appendages elongate, smaller than segment $\mathrm{X}$, setose, digitate, rounded at apex (Figures 2, 3). Inferior appendages broad at base, with apical portion elongate, digitate, setose; basodorsal process short, flat, rounded apically; mesodorsal process digitate, slender, with approximately half-length of apical portion, rounded at apex, dorso-medially directed; basoventral protuberance setose, small as viewed laterally, enlarged in ventral view; mesoventral process enlarged, rounded in lateral view, elongate, digitate, rounded at apex, as viewed ventrally (Figures 2, 4). Phallic apparatus with phallic apodeme and phallobase well developed; phallobase with pair of dorsally directed, acuminate flanges, not laterally directed; phallotremal sclerite moderately developed, roughly U-shaped as viewed dorsally (Figures 5, 6).

Holotype male: BRAZIL: São Paulo: Campos do Jordão, Parque Estadual de Campos do Jordão, afluente do Córrego Galharada, $22^{\circ} 41^{\prime} 30^{\prime \prime} \mathrm{S}, 45^{\circ} 27^{\prime} 36^{\prime}$ 'W, el. $1600 \mathrm{~m}, 07 . \times .2007$, M.R. Spies leg. (MZSP).

Paratypes: BRAZIL: São Paulo: Campos do Jordão, Parque Estadual de Campos do Jordão, afluente do Córrego Galharada, $22^{\circ} 41^{\prime} 30^{\prime \prime} \mathrm{S}$ and $45^{\circ} 27^{\prime} 36^{\prime}$ 'W, el. 1515 m, 07.x.2007, M.R. Spies leg. 3 males (DZRJ 3517); same data, 2 males (MZSP); Campos do Jordão, Parque Estadual de Campos do Jordão, Córrego Galharada, $22^{\circ} 41^{\prime} 40.0^{\prime}$ ' S and 45 27' 37.0" W, el. 1646 m, 07.x.2007, M. R. Spies leg., 3 males (DZRJ 3518); same data 3 males (MZSP); Campos de Jordão, Parque Estadual de Campos do Jordão, afluente do Rio Sapucaí, 22 $2^{\circ}$ 41' 04" S and 45 28' 29" W, el. 1551 m., 22.viii.2006, M.R. Spies leg., 3 males, (DZRJ 3519); Campos de Jordão, Parque Estadual de Campos do Jordão, Córrego do Serrote, 22 $32^{\circ} 30^{\prime \prime} \mathrm{S}$ and $45^{\circ} 26^{\prime} 32$ ' W, el. 1540 m, 20.viii.2006, M.R. Spies leg., 3 males (DZRJ 3520); Campos de Jordão, Parque Estadual de Campos do Jordão, Córrego Galharada, 4a ordem, $22^{\circ} 41^{\prime} 29^{\prime \prime} \mathrm{S}$ and $45^{\circ} 27^{\prime} 36^{\prime \prime}$ W, 07.x.2007, M. R. Spies leg., 1 male (MZSP); Campos do Jordão, Parque Estadual de Campos do Jordão, Córrego Galharada, $22^{\circ} 41^{\prime}$ 26" S and 45 28' 02" W, el. $1548 \mathrm{~m}, 10$.viii - 06.ix.2005, malaise trap, M.R. Spies leg., 1 male, (DZRJ 3521); Campos do Jordão, Parque Estadual de Campos do Jordão, Córrego Galharada, 22 41' $26^{\prime \prime} \mathrm{S}$ and $45^{\circ} 28^{\prime}$ 02" W, el. $1548 \mathrm{~m}, 21$.viii - 21.ix.2006, malaise trap, M.R. Spies leg., 1 male, (MZSP); Campos de Jordão, Parque Estadual de Campos do Jordão, Córrego do Serrote, $22^{\circ} 39^{\prime} 30^{\prime \prime} \mathrm{S}$ and $45^{\circ} 26^{\prime}$ 32.0” W, el. 1530 m, 20.viii.2006, M. R. Spies leg., 2 males (MZSP); Campos de Jordão, Parque Estadual de Campos do Jordão, Córrego do Campo do Meio, 22 $2^{\circ} 41^{\prime} 56.0^{\prime}$ S and 45 29' 19.0” W, el. $1547 \mathrm{~m}$, 21.viii.2007, M. R.. Spies leg., 1 male (MZSP); Campos do Jordão, Parque Estadual de Campos do Jordão, Córrego Celestina, $22^{\circ} 41^{\prime}$ 23" S and 45 28' 26" W, el. 1527 m, 19.viii.2006, M.R. Spies, leg. 1 male (DZRJ 3522). Minas Gerais: Itamonte, Rio Aiuruoca, $22^{\circ} 20^{\prime}$ 56.9" S and 44 41' 57.9" W, el. 1860 m., 25.x.2002, J. L. Nessimian \& A. A. Huamantinco leg., 1 male (DZRJ 1871).

Distribution: Southeastern Brazil (São Paulo and Minas Gerais States). 

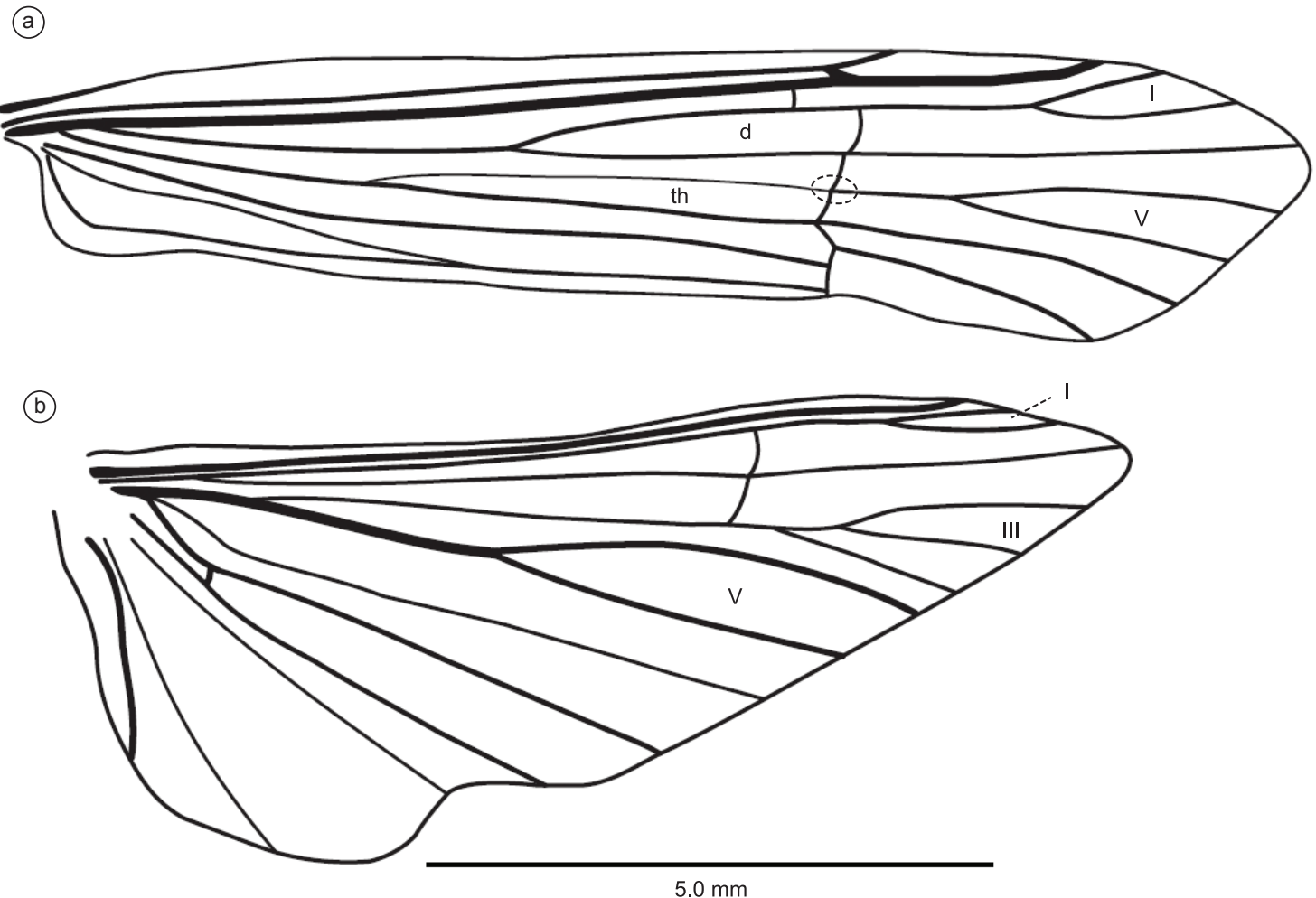

Figure 1. Notalina jordanensis Henriques-Oliveira, Spies \& Dumas, new species. Male wing: a) Forewing; b) Hindwing.

Figura 1. Notalina jordanensis Henriques-Oliveira, Spies \& Dumas, espécie nova. Asa masculina: a) Asa anterior; b) Asa posterior.

Etymology: The epithet specific name jordanensis refers to the holotype locality, Campos do Jordão municipality, in São Paulo State, Southeastern Brazil.

\section{Key to the males of Notalina (Neonotalina)}

(modified from Holzenthal 1986)

1. Phallobase with paired, acuminate flanges; phallotremal sclerite well developed, large (see Figures 3D, E in Holzenthal 1986) brasiliana group

1'. Phallobase with paired, spatulate flanges; phallotremal sclerite underdeveloped, small (see Figures 9D, E in Holzenthal 1986) roraima group

2. Abdominal segment $X$ bearing a single pair of terminal processes (see Figures 5A, B in Holzenthal 1986)

2'. Abdominal segment $X$ bearing 2 pairs of terminal, finger-like processes (see Figures 3A, B in Holzenthal 1986)

3. Segment $X$ with dorsolateral processes (see Figures $2 \mathrm{~A}, \mathrm{C}$ in Calor, Holzenthal \& Amorim 2006).

N.paulista

3'. Segment $X$ without dorsolateral processes

4. Terminal processes of segment $X$ large, quadrate in dorsal view; segment $\mathrm{X}$ with pair of lateral protuberances (see Figures 5A, B in Holzenthal 1986)

4'. Terminal processes of segment $X$ small; segment $X$ without lateral protuberances (see Figures 8A, B in Holzenthal 1986) N. hamiltoni

5. Segment $X$ saddle-shaped in lateral view; inferior appendage narrow basally and bearing 2 sclerotized points mesoventrally (see Figures 5A, C in Holzenthal 1986)

N. morsei

5'. Segment $\mathrm{X}$ not as above; inferior appendage with basal region massive and bearing a lateral ridge (see Figures 7A, C in Holzenthal 1986)
6. Segment X with a setose, mound-like protuberance mesodorsally; inferior appendages with mesoventral process rounded in lateral view (Figures 2, 3, 4)

$N$. jordanensis

6'. Segment X without mound-like protuberance; inferior appendages with mesoventral process elongate (see Figure $3 \mathrm{~A}$ in Holzenthal 1986)

7. Segment $X$ with phallotremal sclerite greatly enlarged, with anteriorly-directed projection (see Figures 3A, B, D, E in Holzenthal 1986)

N. brasiliana

7'. Segment X with dorsomesal processes not surpassing or with same length of ventrolateral processes; phallotremal sclerite not greatly enlarged, without projection (see Figures 2A, E in Calor 2008)

8. Phallobase with pair of laterallly directed, acuminate flanges (see Figures 1D, E, F in Calor, Holzenthal \& Amorim 2006) N. froehlichi

8'. Phallobase with pair of dorsally directed, acuminate flanges (see Figures 2B, D, F in Calor 2008)

N. goianensis

9. Segment $X$ with apex entire or with a very slight mesal cleft; without heavy setae (see Figures 9B, 10B in Holzenthal 1986) 10

9'. Segment X with a deep apico-mesal cleft and bearing heavy setae (see Figures 11A, B in Holzenthal 1986) N. matthiasi

10. Inferior appendages with basal and apical portion long and slender, bearing a sharply pointed mesoventral projection (see Figures 9A, C in Holzenthal 1986)

N. roraima

10 '. Inferior appendages with basal portion broad, lacking pointed mesoventral projection (see Figures $10 \mathrm{~A}, \mathrm{C}$ in Holzenthal 1986)

N. nanay 

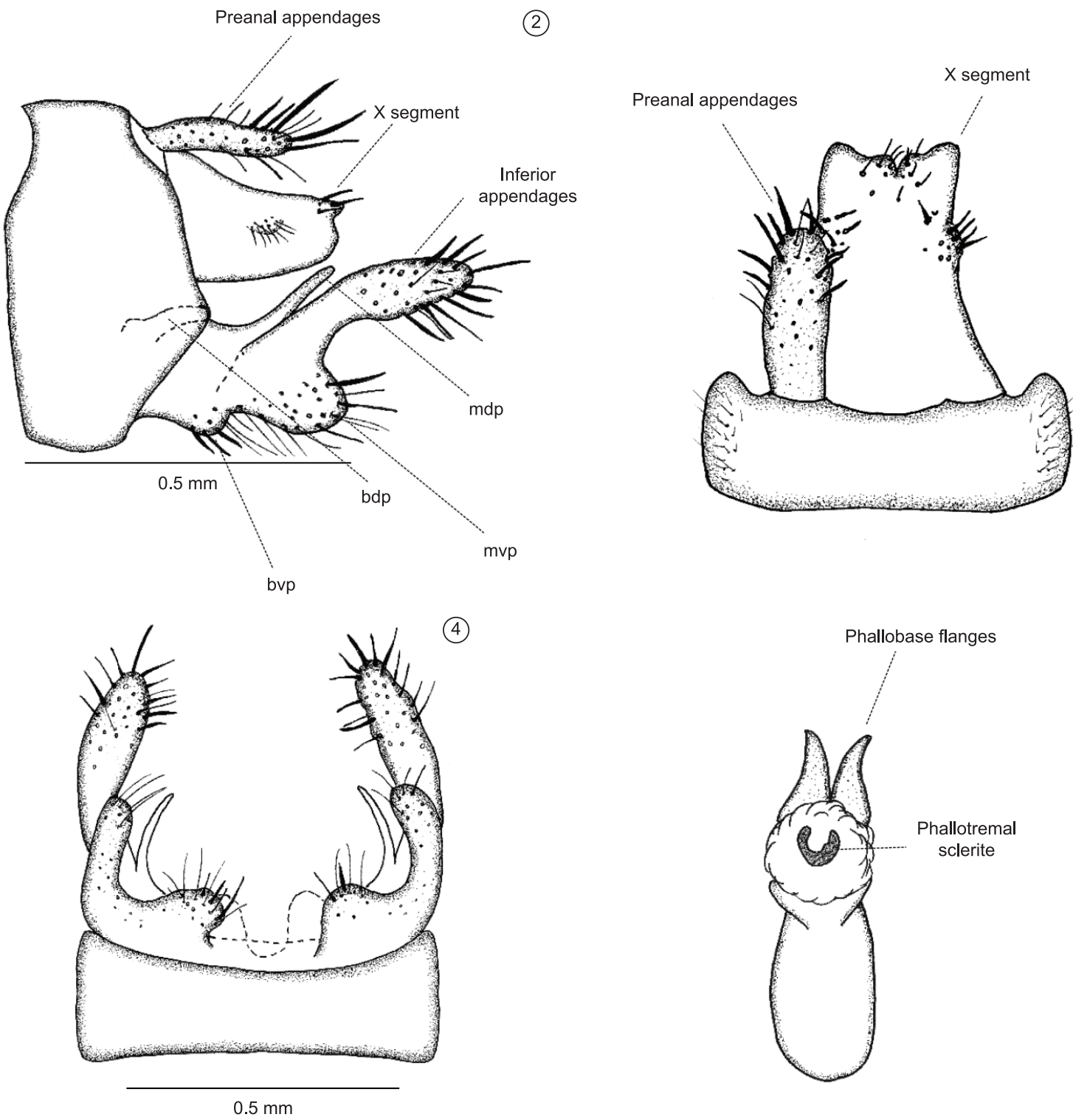

(5)

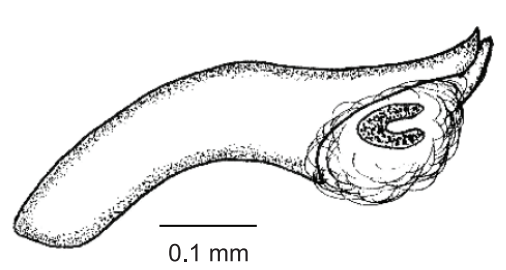

(6)

Figures 2-6. Notalina jordanensis Henriques-Oliveira, Spies \& Dumas, new species. Male genitalia: 2) Abdominal segments IX and X (lateral view). Abbreviations: bvp-basoventral protuberance, mvp-mesoventral process, bdp-basodorsal process and mdp-mesodorsal process; 3) Abdominal segments IX and X (dorsal view), preanal appendages left omitted; 4) Abdominal segments IX and inferior appendages (ventral view); 5) Phallic apparatus (ventral view); 6) Phallic apparatus (lateral view).

Figuras 2-6. Notalina jordanensis Henriques-Oliveira, Spies \& Dumas, espécie nova. Genitália masculina: 2) Segmentos abdominais IX e X (vista lateral) Abreviações: bvp-protuberância basoventral, mvp-processo mesoventral, bdp-processo basodorsal e mdp- processo mesodorsal.; 3) Segmentos abdominais IX e X (vista dorsal); 4) Segmento abdominal IX e apêndice inferior (vista ventral); 5) Aparato fálico (vista ventral); 6) Aparato fálico (vista lateral).

\section{Acknowledgements}

We thank anonymous referees whose advice and suggestions considerably improved the manuscript. The Instituto Brasileiro do Meio Ambiente e dos Recursos Naturais Renováveis (IBAMA),
Instituto Chico Mendes de Conservação da Biodiversidade (ICMBio), and Instituto Florestal (IF) are thanked for issuing collecting permits. This study was partially supported by BIOTA/FAPESP, CNPq and FAPERJ. 


\section{References}

CALOR, A.R. 2008. A new species of Notalina Mosely, 1936 (Trichoptera: Leptoceridae) from Chapada dos Veadeiros National Park, Goiás state, Brazil. Biota Neotrop. 8 (3): http://www.biotaneotropica.org.br/v8n3/en/ abstract?article+bn02108032008.

CALOR, A.R., HOLZENTHAL, R.W. \& AMORIM, D.S. 2006. Phylogenetic analysis of Notalina (Neonotalina) Holzenthal (Trichoptera: Leptoceridae), with the description of two new species from southeastern Brazil. Zootaxa 1131:33-48.

FROST, S.W. 1957. The Pensylvannia insects light trap. J. Econ. Entomol. 50:287-292.
HOLZENTHAL, R.W. 1986. The Neotropical species of Notalina, a southern group of long-horned caddisflies (Trichoptera: Leptoceridae). Syst. Entomol. 11:61-73. http://dx.doi.org/10.1111/j.1365-3113.1986. tb00165.x

MALM, T. \& JOHANSON, K.A. 2011. A new classification of the longhorned caddisflies (Trichoptera: Leptoceridae) based on molecular data. BMC Evol. Biol. 11(10):17. http://dx.doi.org/10.1186/1471-2148-11-10

MORSE, J.C. \& HOLZENTHAL, R.W. 1987. Higher classification of Triplectidinae (Trichoptera: Leptoceridae). In International Symposium on Trichoptera (M. Bournaurd \& H. Tachet, eds.). p.136-143. http://dx.doi. org/10.1007/978-94-009-4043-7_24 